\title{
OBITUARIES
}

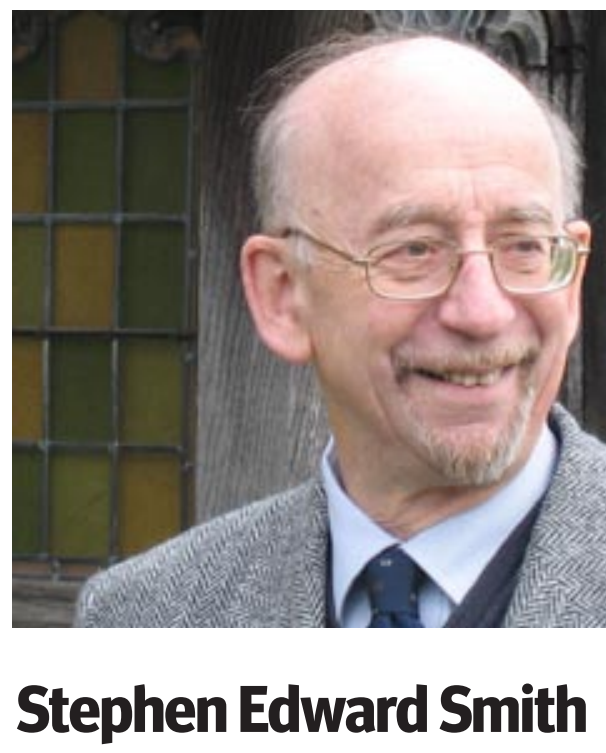

Pharmacologist who unravelled genetic response to drugs and the effect of drugs on the eye

Stephen Smith, emeritus professor of applied pharmacology and therapeutics at St Thomas's, made his reputation for his work on genetic responses to drugs and for the effects of drugs on the eye. His early research was concerned with individual differences in reactions to drugs, and he was one of the first people to undertake twin-based studies. Later, his work on the eye showed how the effects of drugs on the pupil could aid diagnosis of neuro-ophthalmological diseases.

He was born Stephen Schmitt, the son of an English-born German Jewish mother and German father. His parents separated shortly after he was born-he later felt they should never have married. His mother changed their name to Smith in the 1930s. Aged 8, he was sent to a progressive Hampstead preparatory school on the recommendation of Vera Brittain, a friend of his mother. Here he developed his musical talents but learnt little else. In 1939 he won a choral scholarship to Christ Church Cathedral School in Oxford, where he developed his love of music and drama, and played Mole to Jan (then James) Morris's Toad in the school play. Around this time his mother and grandparents moved to Christchurch, Hampshire, and his mother became live-in housekeeper to a local gen- eral practitioner, Mary Mitchell. So Stephen was brought up in a medical household; and the two women remained friends for the rest of their lives. His mother later qualified as a psychiatric social worker and was awarded an OBE.

From Westminster School he went to Christ Church, Oxford (1947-51), where, he said, he spent as much time practising music and singing as he did studying medicine. He turned down a much coveted place at the Radcliffe Infirmary to do his clinical studies at St Thomas's, graduating in 1954. After house jobs in emergency medicine, medicine, and anaesthetics he was called up for national service, spent with little to do in a Colchester military hospital. Here he did his first research, evaluating a new anaesthetic for May and Baker. It was supposed to be short acting, and his task was to compare it with thiopentone and find out how much shorter it was. He found that it was, in fact, longer lasting-research that could have saved the company a lot of money if it had done it before launching the product. At the end of his service he knew that anaesthetics was not for him but that pharmacology research was, and accepted an offer in the pharmacology department at St Thomas's.

Within three years he had a $\mathrm{PhD}$ and a lectureship; five years later he was a senior lecturer and honorary consultant, and he became subdean of the medical school. He stayed at $\mathrm{St}$ Thomas's from 1957 to 1992, taking two years out to drive overland to Burma, where he was Colombo plan adviser in pharmacology in Mandalay and Rangoon during 1965-7. He remained WHO consultant in pharmacology in Rangoon for several years afterwards.

He was often the subject of his own experiments, reporting that $\beta$ blockers made him unbearably sleepless and lethargic. He published 100 papers and gave many lectures and presentations. He was an examiner in pharmacology at a dozen medical schools and served on the editorial board of two pharmaceutical journals and Functional Neurology. He contributed to a dozen books and coauthored Variability in Human Drug Response (1973) with Professor Michael Rawlins, later Professor Sir Michael.

In 1993, when he was 64 and Thomas's pharmacology department was amalgamating with King's and Guy's, he was offered research and clinical facilities-and freedom from administration-at the National Hospital for Nervous Diseases in Queen Square. He remained there for 13 years, until shortly before his death.

Stephen Smith had a warm and outgoing personality. "He taught," said Rawlins, "generations of students not just how drugs worked but how they could best be used to treat patients; his lectures and ward rounds were a byword for how patient focused teaching could and should be conducted." Felicity Reynolds, professor of obstetric anaesthesia, said, "Stephen Smith was a delightful man and a joy to work with. He was a brilliant teacher and lecturer with many devoted friends; he had a gift for friendship."

He married Marjory Murray in 1955; she died young. He married Shirley Taylor, originally his $\mathrm{PhD}$ student, in 1974 . They had two children. After his retirement they both found even greater happiness elsewhere but remained close friends, and Shirley returned to care for him when he was terminally ill. He died in St Christopher's Hospice many years after studying with Cicely Saunders, its founder, and characteristically helped the hospice's fundraising by giving an interview to Libby Purves of the Times while he was dying.

\section{Caroline Richmond}

Stephen Edward Smith, clinical pharmacologist, lecturer, professor, and honorary consultant in clinical pharmacology and therapeutics, St Thomas's Hospital Medical School, London (b 1929; q Oxford/ St Thomas's, 1954; DA, PhD, MA, DM), died from malignant melanoma on 4 December 2007.

OBITUARIES continue on p 223 


\section{William Anthony Campbell Dow}

General practitioner Fremantle, Western Australia (b 1927; q St Mary's Hospital, London, 1952), died after a road crash on 6 November 2007. William Anthony Campbell Dow was a keen climber in his youth. After national service with the Royal Army Medical Corps in Germany, and having been recalled to Cyprus in the Suez crisis, he emigrated to Australia in 1958. He was still in singlehanded practice and active in Fremantle's street doctor organisation at his death. He leaves a wife, Mary; five children; and nine grandchildren. Thomas Campbell Dow

\section{Peter Flamank}

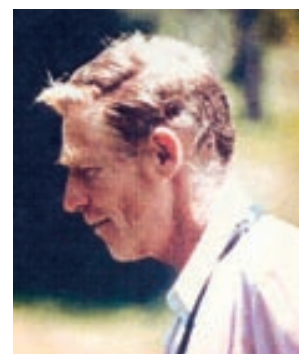

Former general practitioner Plymouth (b 1928; q University College Hospital, London, 1951), died from a ruptured aortic aneurysm on 17 April 2007. As a student, Peter Flamank flew with the University Air Squadron, and was in the university track team. During service in the Royal Air Force he became leader of a medical parachute rescue team. After a hand injury, he gave up surgery and worked in Korea, Iran, Labrador, Pakistan, Abu Dhabi, Indonesia, and Sri Lanka. He was in practice in Plymouth for 15 years, retiring in 1991. He then raced a single seater hillclimb car at weekends until a total hip replacement became infected. He leaves a wife, Iris; four children; and three grandchildren. Martin Flamank

\section{Dudley Fairman Heath}

Former general practitioner Birmingham (b 1911; q Birmingham 1934; VRD), d 9 October 2007. In 1935 Dudley Fairman Heath joined a practice in Selly Oak, Birmingham,

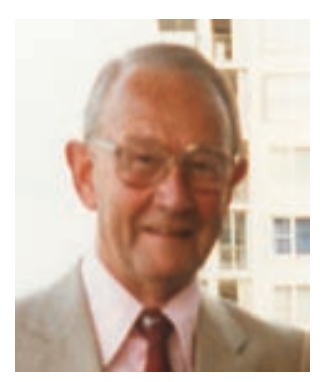

where he was expected for patient visits to wear a suit, hat, and white gloves and travel in a daily washed car. He enlisted in the Royal Naval Volunteer Reserve in 1939, serving in the North Atlantic on destroyers and in Gibraltar, eventually retiring as surgeon commander in 1954 , when he was awarded the volunteer reserve decoration. In 1945 Dudley returned to his former practice, where he was active in medicopolitics until he retired in 1985. He served on the General Medical Services Committee from 1958 to 1986 and was elected a fellow of the BMA in 1964. Predeceased by his wife, Margery, and a daughter, he leaves a son and four grandchildren.

Michael Hickman

\section{Gunter Holti}

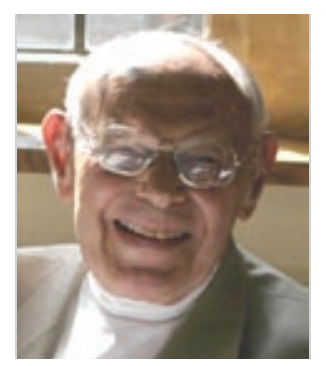

Former consultant dermatologist Newcastle Royal Victoria Infirmary and Freeman Hospitals (b 1919; q Leeds 1951; MD, FRCP), died from leukaemia on 21 September 2007.

Gunter Holti began his medical studies in Prague but interrupted them to serve in the British Army during the second world war in Europe and North Africa. After graduating from Leeds, he did research for the Medical Research Council in Birmingham while also a clinical registrar at Queen Elizabeth Hospital. In 1959 he was appointed consultant dermatologist in Newcastle on Tyne, retiring in 1984. He published on erythropoietic protoporpyria, systemic sclerosis, and corticosteroid treatment. One time president of the British Microcirculation Society, Gunter continued with medicolegal work into his retirement, principally in relation to vibration white finger. $\mathrm{He}$ leaves a wife, Gillian; three children; and six grandchildren.

Anne Cullen, Richard Holti, Poppy Martin

\section{Alistair David Mclntosh}

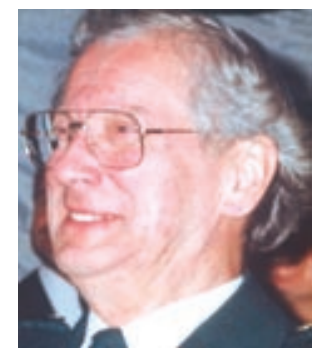

Former consultant obstetrician and gynaecologist Raigmore Hospital, Inverness (b 1921; q Edinburgh 1944; FRCOG), died from bronchopneumonia on 29 June 2007. After qualifying Alistair David McIntosh ("David") served in the Pacific Fleet on HMS Alacrity, Glory, and Implacable. On leaving the navy in 1948, he started his career in obstetrics and gynaecology and in 1959 became a consultant in Lanarkshire, in the then new Bellshill Hospital. In 1964 he moved to Raigmore Hospital. His special interest was pelvic floor surgery. After retirement in 1982 he served on the Highland Health Board, including as vice chairman. A fellow of the Royal College of Obstetrics and Gynaecology, he was an active member of the council between 1962 and 1968. Predeceased by his wife, Margaret, he leaves three children and eight grandchildren.

G Ewan Mclntosh

\section{Philip Lawrence Robinson}

Former general physician Clatterbridge Hospital, Wirral (b 1920; q Liverpool 1942; MD, FRCP), died from prostate cancer on 27 June 2007. In the second world war Philip Robinson joined the Royal Army Medical Corps, serving in troopships. As a consultant he developed one of the first modern departments of geriatric medicine, training

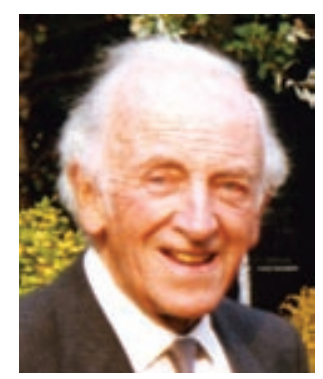

many doctors with an interest in the specialty. He became regional adviser for the Royal College of Physicians, and vice chairman of Liverpool University's postgraduate advisory panel. He was the first secretary of the Merseyside branch of the British Geriatrics Society, and was awarded the society's 50th anniversary medal for outstanding services to geriatric medicine. He leaves two children and two grandchildren.

John A Aitken

\section{Gavin Brown Shaw}

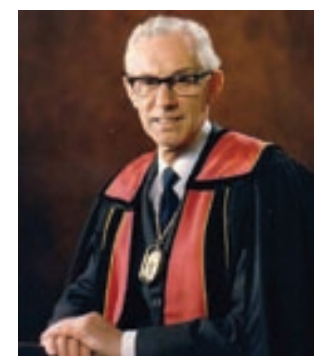

Former consultant cardiologist Southern General Hospital, Glasgow (b 24 May 1919; q Glasgow 1942; CBE, BSc, FRCP), d 11 November 2007. After qualifying, Gavin Brown Shaw served as surgeon lieutenant in the Royal Naval Volunteer Reserve in the Far East and Pacific. He was appointed senior registrar at the Southern General in 1948, consultant cardiologist in 1956, and consultant in charge of wards in 1963, retiring in 1984. He pioneered the use of cardiac pacemakers and cardiac resuscitation and the development of medical services and postgraduate medical education in greater Glasgow. Past president of the Royal College of Physicians and Surgeons of Glasgow, he was influential in developing its status as a leading postgraduate educational institute. Predeceased by his wife, Margaret, and two children, he leaves a daughter and six grandchildren.

Tom Drysdale 